\title{
The Role of Body Mass Index in High and Low Velocity Trauma Causing Knee Injury Associated to Popliteal Artery Lesions.
}

Andrea Ascoli Marchetti ( $\square$ ascolimarchetti@med.uniroma2.it )

Universita degli Studi Roma Tor Vergata https://orcid.org/0000-0001-9229-0495

Valerio Naldi

Vascular Surgery Unit Biomedicine and Prevention Department

Vito Potenza

Orthopedic and Traumatology Unt. Surgical science Department

Fabio Massimo Oddi

Vascular Surgery Unit. Biomedicine and Prevention Department

Fernando De Maio

Orthopedic and Traumatology Unit. Surgical Science Department

Riccardo Ciattaglia

Vascular Surgery Unit. Biomedicine and Prevention Department

Pasquale Farsetti

Orthopedid and Traumatology Unit.

Arnaldo Ippoliti

Universitatsklinikum Schleswig Holstein Klinik fur Herz und thorakale Gefasschirurgie

\section{Research article}

Keywords: BMI, knee trauma, popliteal artery, revascularisation, vein graft, vascular injury, multidisciplinary

Posted Date: September 14th, 2020

DOI: https://doi.org/10.21203/rs.3.rs-59520/v1

License: (c) (i) This work is licensed under a Creative Commons Attribution 4.0 International License.

Read Full License 


\section{Abstract}

Background: Osteoarticular traumas are particularly dangerous among arterial traumas, those associated with the popliteal artery are associated with a high amputation rate. Despite representing a minority of arterial traumas, with an incidence that considerably varies by population and geographic location, traumatic lesions of the popliteal artery are a challenge. This study aimed to verify the impact of Body Mass Index (BMI) on arterial trauma damage and outcome.

Methods: Data were retrospectively collected from the emergency and operating rooms' electronic medical reports at our Institution between 1 January 2005 and 1 May 2018 of all osteoarticular and vascular associated lesion. 41 pts presented with lower limb arterial trauma (43.2\%), and popliteal artery lesions occurred in 11 (26.8\%). 11 patients were eligible for inclusion in the study. In addition, the lesion mechanism was dislocation by high-velocity trauma in 9 cases and by low-velocity trauma in 3 . All 7 males (63.6\%) were affected by high-velocity trauma, and 2 of the 3 females by low-velocity trauma. Only one patient had an isolated popliteal artery lesion associated with fractures in the leg or in contralateral limb. Patients with low-velocity traumas were older than 54 years while those with high-velocity were aged from 22 to 71 years.

Results: The lesion mechanism was dislocation due to high-velocity trauma in eight patients and due to low-velocity trauma in three. In 10/11 patients (90.9\%). revascularization was performed after osteoarticular stabilization. after reduction of the dislocation or fracture. Intraoperative angiography was selectively used. Two patients required above-knee amputation after the procedure: one due to infection of the surgical access and the other due to severe soft tissue injury. One patient died during hospitalization due to trauma-related complications and comorbidities.

Conclusions: High-velocity traumas, and low-velocity traumas with a body mass index $>35 \mathrm{~kg} / \mathrm{m} 2$ with knee lesions are associated with popliteal artery lesion. Revascularization success is not associated with high or low velocity traumas.

\section{Background}

Traumatic lesions of the popliteal artery are rare ${ }^{1,2}$, with an incidence rate between $5 \%$ and $19 \%$ in the civilian population ${ }^{3,4}$. Because of its anatomical position in the popliteal fossa, because of which it is anteriorly protected by the knee joint, it is barely affected by isolated traumas. It is more frequently associated with knee fractures (Gustillo IIIC) ${ }^{5,6}$ or knee dislocation 7,8 . Ligation of arterial injuries of the leg in World War II led to an amputation rate of $72 \%{ }^{9}$, and experience with arterial repair or reconstruction in the Korean War lowered the amputation rate to $32 \% 10$. More than a decade later, similar amputation rates were reported from the Vietnam $\mathrm{War}^{11}$. Although a much lower amputation rate has been reported in years between 1990 and 2000, traumatic lesions of the popliteal artery continue to be the arterial lesion most associated with limb loss ${ }^{12,13}$. A multidisciplinary approach is still key in the successful management of knee injury. Dislocation or fracture can cause a vascular lesion and must be recognized 
quickly for imminent repair. The osteoarticular cause must also be identified for appropriate revascularization. Surgeons should always consider the possibility of a popliteal artery lesion, even in cases of minor trauma ${ }^{14,15}$. Few studies focus on the relationship between speed and mass. This study aimed to evaluate arterial injury-associated risk factors of trauma and verify the role of body mass on the outcome of surgical arterial revascularization.

\section{Methods}

This is a retrospective analysis of a monocentric experience. No Ethical approval, or relevant judgement reference from ethics committees is required. Prior to initiating the writing of this document, all patients and/or family members were contacted to seek their consent for the release and processing of sensitive data for research purposes. Main inclusion criteria were traumatic lesions of the popliteal artery and a patient older than 18 years at the time of admission. Exclusion criteria was arterial lesion not involving limbs. Another criterion was absence of a diagnosed popliteal artery lesion (such as popliteal artery aneurysm) prior to trauma and admission to the hospital. The patients were divided into two study groups based on the dynamics that produced the arterial lesion: "high" or "low" velocity. A high-velocity injury was one in which the trauma involved a motorized vehicle, such as motor vehicle collisions, motorcycle collisions, moped collisions, motorized vehicle collisions, or crush injuries. A low-velocity injury was defined as trauma occurring secondary to a fall, a sport, or an assault 8,14 . Clinical and operative data were retrospectively collected from the emergency and operating rooms' electronic medical reports at Tor Vergata Hospital between 1 January 2005 and 1 May 2018. Ninetyfive patients were admitted to Tor Vergata Hospital with a diagnosis of arterial trauma (Table 1). Inclusion criteria was popliteal artery injury, so of these, 42 presented with lower limb arterial trauma (44.2\%) and in these cases popliteal artery lesions occurred in 11 (26.8\%). 10 patients were eligible for inclusion in the study. In addition, the lesion mechanism was dislocation by high-velocity trauma in 9 cases and by low-velocity trauma in 2 . All 7 males (70\%) were affected by high-velocity trauma, and 2 of the 3 females by lowvelocity trauma. Three patients had popliteal artery lesions and knee dislocation (all posterior dislocation), two of whom had a total knee prosthesis; five patients had knee fractures associated with popliteal artery trauma and one patient had knee fracture and dislocation involving the popliteal artery. Only one patient had an isolated popliteal artery lesion associated with fractures in the leg or in contralateral limb. Patients with low-velocity traumas were older than 54 years while those with highvelocity were aged from 22 to 71 years.

\section{Statistical Analysis}

IBM SPSS Statistics (IBM Corp., Armonk, New York, NY, USA, Version 20) was used for statistical analysis. Categorical variables were presented as values with percentages. Detailed on open surgical procedure were recorded. Indication for open surgical repair, open surgical approach, and technique were calculated and analysed. Additionally, post-open surgical complications and intra-operative death, length of stay, hospital mortality, long-term mortality, and re-intervention rates were assessed. Groups were compared with non-parametric statistical tests; categorical variables were compared. 


\section{Results}

All patients were treated within 3 hours from admission to the emergency room and within 6 hours from the accident. In eight patients, revascularization was performed after osteoarticular stabilization, except for one patient in whom revascularization was performed before orthopaedic surgery due to bleeding from the artery. One patient only required arterial reconstruction without subsequent collaboration with orthopaedists due to the absence of fractures or dislocations. In most part of the popliteal area involvement, $9 / 11$ (81,8\%) were used posterior surgical access to the knee, with only two patients $(18.1 \%)$ requiring the medial approach. The posterior approach was also chosen to allow orthopaedists to work with a single access, while patients with particularly complicated situations, especially in posterior knee dislocations or pluriframmentary fractures, required the medial approach. In every surgery, systemic heparinization was performed, except in a haemophilic patient with increased risk of intraoperative bleeding. Treatments were performed according to the lesion, availability of the great saphenous vein (GSV) of adequate calibre (at least $3 \mathrm{~mm}$ in diameter), and, where possible, it was preferred to perform end-to-end anastomosis of the popliteal artery. Three patients were treated with GSV graft, four by end-toend anastomosis of the popliteal artery without any graft, and three by synthetic grafting due to an inadequate GSV calibre. Revascularization of the popliteal artery was successful in seven cases out of 11, where two patients underwent amputation above the knee. One of the two patients was a 54-year old obese woman (BMl=40 kg/m2) who had rheumatoid arthritis and drug-induced osteoporosis due to corticosteroid therapy and who experienced low-velocity trauma from falling. Her knee prosthesis was dislocated after her fall from an upright position, which injured her popliteal artery. Because of her immune dysfunction due to rheumatoid arthritis and she was administered corticosteroid therapy, she was affected by a multi-drug resistant infection of the surgical wound that made amputation necessary after 2 months of medical therapy. A second patient was 24-year-old man who attempted suicide by falling from a height of 12 meters and who underwent bilateral GSV graft revascularization and osteoarticular stabilization but who ultimately required above-knee amputation due to extensive soft tissue injury. A third patient was worsened by haemophilia type A died 6 months after GSV procedure due to the extensive injuries caused by the accident. The septic shock despite antibiotic prolonged therapy, together with traumatic soft tissue injuries, resulted in the patient's death, but graft patency was maintained. Cases of patients treated with revascularization due to a popliteal artery injury are described in Table 2, which shows that there was no difference in revascularization success between high-velocity and low-velocity trauma patients. All patients were intraoperative submitted to Eco-duplex. Intraoperative angiography was used in only one patient. Two patients needed above-knee amputation before 30 days after the procedure: one due to infection of the surgical access and the other due to severe soft tissue injury. Revascularization of the popliteal artery was successful in seven cases out of 11, where two patients underwent amputation above the knee. A second patient was 24 -year-old man who attempted suicide by falling from a height of 12 meters and who underwent bilateral GSV graft revascularization and osteoarticular stabilization but who ultimately required above-knee amputation due to extensive soft tissue injury. A third patient was worsened by haemophilia type A and died 6 months after GSV procedure due to the extensive injuries caused by the accident, as well as surgical wound infection. Despite the 
prolonged antibiotic therapy, septic shock together with traumatic soft tissue injuries, resulted in the patient's death, but graft patency was maintained. Cases of patients treated with revascularization due to a popliteal artery injury are described in Table 2, which shows that there was no difference in revascularization success between high-velocity and low-velocity trauma patients. One patient died during hospitalization due to trauma-related complications and comorbidities, namely haemophilia type A, despite maintaining graft patency. Among the complications, there were two patients with deep venous thromboses $(6.4 \%)$, and two patients $(6.4 \%)$ healed by secondary intention. Follow-up was available for 6 of 8 salvaged limbs over a mean 12-month period where all patients maintained patency of arterial reconstruction, vein graft, or synthetic graft. Further, 1-year patency was maintained in three cases of endto-end anastomoses, one case of GSV graft, and two cases of synthetic grafting.

\section{Discussion}

Popliteal artery traumas represent a minority of arterial traumas likely due to their anatomical position in the popliteal fossa and their location, which is posterior to the knee joint. Unless there are pre-existing structural lesions (aneurysms) or genetic predispositions such collagenopathy, Ehlers-Danlos Syndrome, etc... (laxity of joint ligaments), high-velocity traumas are required to disrupt the knee joint. Although rare, cases of low-velocity traumas exist; these can cause damage to the joint and involve the popliteal artery. This is dangerous, because of the low velocity of trauma associated with a large weight can be equally dangerous and inconsistent signs and symptoms may evident; typical signs of arterial injury are absent in up to $40 \%$ of patients, where the presence of a pulse in the affected limb does not exclude an arterial lesion and segmental Doppler may not detect the injury ${ }^{16-19}$. This type of injury does not depend only on the trauma dynamic (as with high-velocity traumas) but instead on the patient's risk factors. According to the literature, the keys for effective revascularization are systemic heparinization ${ }^{20-22}$, performing revascularization between 6 and 8 hours9, and end-to-end anastomosis instead of using a GSV graft or synthetic graft. Wherever possible, we preferred end-to-end anastomosis over GSV grafting because it is associated with a higher success rate13. Furthermore, several authors have suggested that fibromuscular tethering of the artery in the popliteal fossa precludes tension-free anastomosis, unless potentially critical perigeniculate collaterals are divided. Therefore, they advocate interposition or bypass grafting in such cases $20,23,24$. Extension of soft tissue injuries is crucial for adequate and successful revascularization; this is the reason amputation rates due to reason arterial injury from secondary blunt trauma are double those due to injury from penetrating trauma ${ }^{25}$. Both patients affected by low-velocity trauma had a BMI greater than $35 \mathrm{~kg} / \mathrm{m} 2$ while patients affected by high-velocity trauma had a BMI between 18.7 and 31.5 $\mathrm{kg} / \mathrm{m} 2$. The advanced age of patients affected by low-velocity trauma could represent a predisposing factor with regard to diseases associated with aging such as osteoporosis, arthrosis, and ligamentous laxity, rendering them prone to fractures or dislocations, even of the knee joint, as body weight represents a strong risk factor for low-velocity trauma fractures and dislocations ${ }^{8,14,26}$. In three cases of our experience patients had a knee prosthesis dislocation, a rare but possible cause of popliteal artery injury, especially in posterior dislocations; with this condition the disruption of ligaments, is also described by Bonnevialle et coll. in concomitant palsy of the common peroneal nerve ${ }^{27,28}$. Our findings align with 
those in the literature in that there was no correlation between the dynamics of the trauma and the success of revascularization. This study has some limitations. The first was the small number of patients since our Institution is not a trauma centre and popliteal artery traumas have a low incidence. Furthermore, as in the literature reviews, there is no single definition of low/high-velocity trauma. Therefore, different articles may differ in results depending on their interpretation. Finally, as patients in this study were from a specific population, the findings about mass/velocity data cannot be extrapolated to the general population. The statistically significant conclusions will be drawn only after more data collection. However, this correlation remains very suggestive and can be deepened with further studies.

\section{Conclusion}

The traumatic lesions of the popliteal artery following low-velocity trauma are correlated with high BMI of $>35 \mathrm{~kg} / \mathrm{m} 2$ and must considered in orthopaedic evaluation. Secondly, trauma dynamics (low- or highvelocity) do not influence the success of revascularization. Instead, factors that influence the results are revascularization procedure between 6 and 8 hours after the accident, intraoperative systemic heparinization, and an appropriate technique of revascularization and extension of soft tissue injuries. There may be an association between age and susceptibility to arterial trauma relative to low-velocity trauma; however many 9 more risk factors should be analysed and a greater number of cases would be needed. Further in-depth studies should be conducted to support this association.

\section{Abbreviations}

body mass Index (BMI)

great saphenous vein (GSV)

\section{Declarations}

- Ethical Approval. "This is an analysis of a monocentric experience. No formal ethics approval was required in this particular case: retrospective and good medical practice" Independent Ethics Committee at the PTV. Foundation "Policlinico Tor Vergata".

- Consent to participate. All patients and/or family members give their consent for the release and processing of sensitive data for research purposes.

- Consent for publication. All patients give consent for publication.

- Availability of supporting data. All Clinical and operative data were available in emergency and operating rooms' electronic medical reports at our Institution.

- Competing interests. The authors declare no competing interest.

- Funding. The authors declare no funding for the research was provided. 
- Authors' contributions.

AAM literature search, study design, data analysis, data interpretation, writing, critical revision

VN literature search data collection, writing.

FMO data analysis, data interpretation, writing, critical revision.

VP data analysis, data interpretation, writing, critical revision.

PF, data interpretation, writing, critical revision.

FDM data interpretation, writing, critical revision.

Al, data interpretation, writing, critical revision.

All authors have read and approved the manuscript.

- Acknowledgements. no applicable

\section{References}

1. Sher MH. Principles in the management of arterial injuries associated with fracture/dislocations. Ann Surg. 1975; 182(5):630-634.

2. Alberty RE, Goodfried G, Boyden AM. Popliteal artery injury with fractural dislocation of the knee. Am J Surg. 1981; 142(1):36-40.

3. Koivunen D, Nichols WK, Silver D. Vascular trauma in a rural population. Surgery. 1982; 91(6):723727. 10

4. Reynolds RR, McDowell HA, Diethelm AG. The surgical treatment of arterial injuries in the civilian population. Ann Surg. 1979; 189(6):700-708.

5. BASSETT III FH, SILVER D. Arterial Injury Associated With Fractures. JAMA Surg. 1966; 92(1):13-19.

6. Snyder WH. Popliteal and shank arterial injury. Surg Clin North Am. 1988; 68(4):787-807.

7. Daniel C. Wascher M. High-velocity knee dislocation with Treatment Principles. Clin Sports Med. 19(3):457-477.

8. Vaidya R, Roth M, Nanavati D, Prince M, Sethi A. Low-velocity knee dislocations in obese and morbidly obese patients. Orthop J Sport Med. 2015; 3(4):1-8.

9. DeBakey ME SF. Battle injuries of the arteries in World War II. 1946; 123:534.

10. HUGHES CW. Arterial repair during the Korean war. Ann Surg. 1958; 147(4):555-561.

11. Rich NM, Baugh JH, Hughes CW. Popliteal artery injuries in Vietnam. Am J Surg. 1969; 118(4):531534. 
12. Kauvar DS, Sarfati MR, Kraiss LW. National trauma databank analysis of mortality and limb loss in isolated lower extremity vascular trauma. J Vasc Surg. 2011; 53(6):1598-1603.

13. Wagner WH, Calkins ER, Weaver FA, Goodwin JA, Myles RA, Yellin AE. Blunt popliteal artery trauma: One hundred consecutive injuries. J Vasc Surg. 1988; 7(5):736-748.

14. Coleman JJ, Tavoosi S, Zarzaur BL, Brewer BL, Rozycki GS, Feliciano D V. Arterial injuries associated with blunt fractures in the lower extremity. Am Surg. 2016; 82(9):820-824.

15. Martin MJ, Perez-Alonso AJ, Asensio JA. Vascular complications and special problems in vascular trauma. Eur J Trauma Emerg Surg. 2013; 39(6):569-589.

16. Stuebing E, Lieberman H, Vu T, et al. Shank vessel injuries: The forgotten vascular injuries. Eur J Trauma Emerg Surg. 2012; 38(4):393-401. doi:10.1007/s00068-012-0196-8 11

17. Smith RF, Szilagyi DE, Elliott JP. Fracture of Long Bones with Arterial Injury Due to Blunt Trauma: Principles of Management. Arch Surg. 1969; 99(3):315-324.

18. Bishara RA, Pasch AR, Lim LT, et al. Improved results in the treatment of civilian vascular injuries associated with fractures and dislocations. J Vasc Surg. 1986; 3(5):707-711. doi:10.1016/07415214(86) 90033-9

19. Jones RE, Smith EC, Bone GE. Vascular and orthopedic complications of knee dislocation. Surg Gynecol Obstet. 1979; 149(4):554-558.

20. Leonardo T. Lim, MD; Maryanne S. Michuda; D. Preston Flanigan, MD; Arsen Pankovich M. Popliteal Artery Trauma 31 Consecutive Cases Without Amputation. JAMA Surg. 1980; 115 (11):1307-1313.

21. Michael E. Daugherty, MD; Charles R. Sachatello, MD; Calvin B. Ernst M. Using Anticoagulation and Extra-anatomic Reconstruction. JAMA Surg. 1970; 113(11):1317-1321.

22. Snyder WH. Vascular injuries near the knee: An updated series and overview of the problem. Surgery. 1982; 91(5):502-506.

23. O'Donnell TF, Brewster DC, Darling RC, Veen H W, AA. Arterial injuries associated with fractures and/or dislocations of the knee. j trauma. 1977; 17 (775):83.

24. Shah DM, Naraynsingh V, Leather RP, Corson JD K, AM. Adances-in-the-Management-of-AcutePopliteal-vascular-Blunt-Injuries.pdf. j trauma. 1985; 25 (793):7.

25. Mullenix PS, Steele SR, Andersen CA, Starnes BW, Salim A, Martin MJ. Limb salvage and outcomes among patients with traumatic popliteal vascular injury: An analysis of the National Trauma Data Bank. J Vasc Surg. 2006; 44(1):94-100.

26. Azar FM, Brandt JC, Miller RH, Phillips BB. Ultra-low-velocity knee dislocations. Am J Sports Med. 2011; 39(10):2170-2174. 12

27. Bonnevialle P1, Chaufour X, Loustau O, Mansat P, Pidhorz L, Mansat M.Traumatic knee dislocation with popliteal vascular disruption: retrospective study of 14 cases. Rev Chir Orthop Reparatrice Appar Mot. 2006 Dec; 92 (8):768-77.

28. Ascoli Marchetti A, Potenza V, Battistini M, Morelli M, Barbante M, Benedetti Valentini M. Dislocation of the knee and popliteal artery trauma: our experience and literature review November 2012 Journal 
of Orthopaedics and Traumatology J. Orthop. Traumatol. (13): 99

\section{Tables}

Table 1:Arterial injuries between 2005 and 2019 admitted to our Hospital

\begin{tabular}{|lllllll|}
\hline Injury mechanism & $\begin{array}{l}\text { Overrall } \\
\text { group }\end{array}$ & $\begin{array}{l}\text { CFA } \\
\text { lesion }\end{array}$ & $\begin{array}{l}\text { DFA } \\
\text { lesion }\end{array}$ & $\begin{array}{l}\text { SFA } \\
\text { lesion }\end{array}$ & $\begin{array}{l}\text { Popliteal artery } \\
\text { lesion }\end{array}$ & $\begin{array}{l}\text { Tibial arteries } \\
\text { lesion }\end{array}$ \\
\hline Number & 41 & 8 & 5 & 13 & 11 & 5 \\
\hline Gunshot wound & 3 & - & - & 3 & 1 & - \\
\hline $\begin{array}{l}\text { Motorized vehicle } \\
\text { accident }\end{array}$ & 21 & 4 & 4 & 6 & 6 & 1 \\
\hline Stab/ laceration & 6 & 1 & 1 & 3 & - & - \\
\hline Crush injury & 7 & 3 & - & 1 & 1 & 2 \\
\hline Fall & 4 & - & - & - & 2 & 2 \\
\hline Assault & - & - & - & - & - & - \\
\hline Sport & - & - & - & - & - & - \\
\hline
\end{tabular}

Table 2. Popliteal artery lesion associated to trauma of the knee. *8-9 patient with bilateral lesion. Medium age: 45,2 yars ( $\min 22-\max 71$ ) 


\begin{tabular}{|c|c|c|c|c|c|c|c|}
\hline$P t$ & $\begin{array}{l}\text { se } \\
\mathrm{x}\end{array}$ & $\begin{array}{c}\mathrm{BMI} \\
\left(\mathrm{Kg} / \mathrm{m}^{\wedge} 2\right)\end{array}$ & $\begin{array}{l}\text { Trauma } \\
\text { dynamic }\end{array}$ & $\begin{array}{c}\text { Osteoarticular } \\
\text { Trauma }\end{array}$ & $\begin{array}{l}\text { Revasculari- } \\
\text { zation }\end{array}$ & $\begin{array}{l}\text { Postoperative } \\
\text { course }\end{array}$ & comorbidity \\
\hline 1 & $\mathrm{~F}$ & 40,2 & $\begin{array}{l}\text { Low } \\
\text { speed }\end{array}$ & $\begin{array}{l}\text { Knee dislocation of } \\
\text { the knee prosthesis }\end{array}$ & End-to-end & $\begin{array}{l}\text { Amputation } \\
\text { above knee }\end{array}$ & $\begin{array}{c}\text { Reumatoid } \\
\text { arthritis, } \\
\text { osteoporosis, total } \\
\text { knee prosthesis, } \\
\text { hip prosthesis } \\
\text { (bilateral) }\end{array}$ \\
\hline 2 & $\mathrm{M}$ & 27 & $\begin{array}{l}\text { High } \\
\text { speed }\end{array}$ & $\begin{array}{l}\text { Proximal tibial } \\
\text { epiphysis fracture }\end{array}$ & GSV graft & $\begin{array}{l}\text { Discharged. } \\
\text { Manteining } \\
\text { patency. }\end{array}$ & - \\
\hline 3 & M & 31,5 & $\begin{array}{l}\text { High } \\
\text { speed }\end{array}$ & $\begin{array}{l}\text { Knee dislocation of } \\
\text { the knee prosthesis }\end{array}$ & $\begin{array}{c}\text { ePTFE } \\
\text { synthetic } \\
\text { graft }\end{array}$ & $\begin{array}{l}\text { Discharged. } \\
\text { Manteining } \\
\text { patencyv }\end{array}$ & $\begin{array}{l}\text { Arthrosis, total } \\
\text { knee prosthesis }\end{array}$ \\
\hline 4 & $\mathrm{M}$ & 25 & $\begin{array}{l}\text { High } \\
\text { speed }\end{array}$ & $\begin{array}{l}\text { Distal femoral } \\
\text { epiphysis fracture, } \\
\text { proximal tibial } \\
\text { epiphysis }\end{array}$ & $\begin{array}{c}\text { ePTFE } \\
\text { synthetic } \\
\text { graft }\end{array}$ & $\begin{array}{l}\text { Discharged. } \\
\text { Manteining } \\
\text { patency }\end{array}$ & - \\
\hline 5 & $\mathrm{M}$ & 18,7 & $\begin{array}{l}\text { High } \\
\text { speed }\end{array}$ & $\begin{array}{l}\text { Knee dislocation, } \\
\text { vertebral L1 fracture, } \\
\text { pelvis fracture }\end{array}$ & GSV graft & $\begin{array}{l}\text { Deceased due to } \\
\text { traumatic soft } \\
\text { tissue lesions, } \\
\text { infection and } \\
\text { sepsis. }\end{array}$ & Haemophilia A \\
\hline 6 & $\mathrm{M}$ & 26,6 & $\begin{array}{l}\text { High } \\
\text { speed }\end{array}$ & $\begin{array}{c}\text { Proximal tibial } \\
\text { epiphysis fract., tibial } \\
\text { diaphysis frac., fibula } \\
\text { fracture }\end{array}$ & End-to-end & $\begin{array}{l}\text { Discharged. } \\
\text { Manteining } \\
\text { patency }\end{array}$ & - \\
\hline 7 & $\mathrm{~F}$ & 35,8 & $\begin{array}{l}\text { Low } \\
\text { speed }\end{array}$ & Knee dislocation & GSV graft & $\begin{array}{l}\text { Discharged. } \\
\text { Manteining } \\
\text { patency }\end{array}$ & \\
\hline 8 & $\begin{array}{c}\mathrm{M} \\
*\end{array}$ & 25 & $\begin{array}{l}\text { High } \\
\text { speed }\end{array}$ & $\begin{array}{c}\text { Proximal tibial } \\
\text { epiphysis fracture, } \\
\text { Distal femoral } \\
\text { epiphysis fracture, } \\
\text { tibial } \\
\text { multifragmentary } \\
\text { fracture }\end{array}$ & GSV graft & $\begin{array}{l}\text { Amputation } \\
\text { above knee due } \\
\text { to extensive soft } \\
\text { tissue lesion. }\end{array}$ & \\
\hline 9 & $\begin{array}{c}\mathrm{M} \\
*\end{array}$ & 25 & $\begin{array}{l}\text { High } \\
\text { speed }\end{array}$ & $\begin{array}{c}\text { Distal femoral } \\
\text { epiphysis fracture, } \\
\text { tibial } \\
\text { multifragmentary } \\
\text { fracture }\end{array}$ & GSV graft & $\begin{array}{l}\text { Discharged. } \\
\text { Manteining } \\
\text { patency }\end{array}$ & \\
\hline 10 & $\mathrm{~F}$ & 23 & $\begin{array}{l}\text { High } \\
\text { speed }\end{array}$ & $\begin{array}{c}\text { Proximal tibial } \\
\text { epiphysis fracture }\end{array}$ & End-to-end & $\begin{array}{c}\text { Discharged. } \\
\text { Manteining } \\
\text { patency }\end{array}$ & $\begin{array}{l}\text { Arthrosis, } \\
\text { osteoporosis }\end{array}$ \\
\hline 11 & $\mathrm{M}$ & 28,3 & $\begin{array}{l}\text { High } \\
\text { speed }\end{array}$ & Colles fracture & $\begin{array}{l}\text { ePTFE } \\
\text { synthetic } \\
\text { graft }\end{array}$ & - & - \\
\hline
\end{tabular}

\section{Figures}




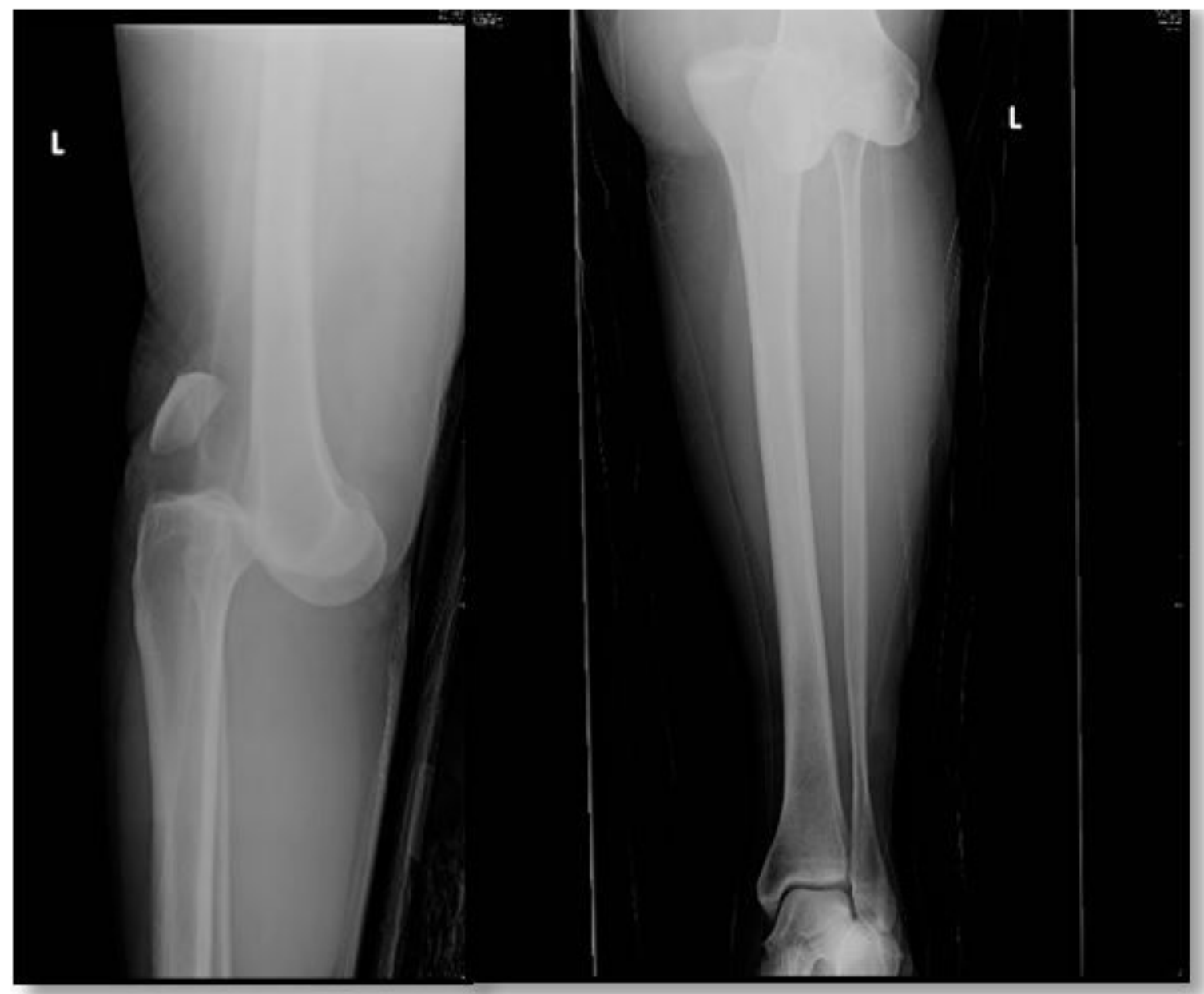

\section{Figure 1}

PT $n^{\circ}$ 7. Plain RX: Posterior dislocation of the knee. Note the posterior descent of the bone segment represented by the femur. 


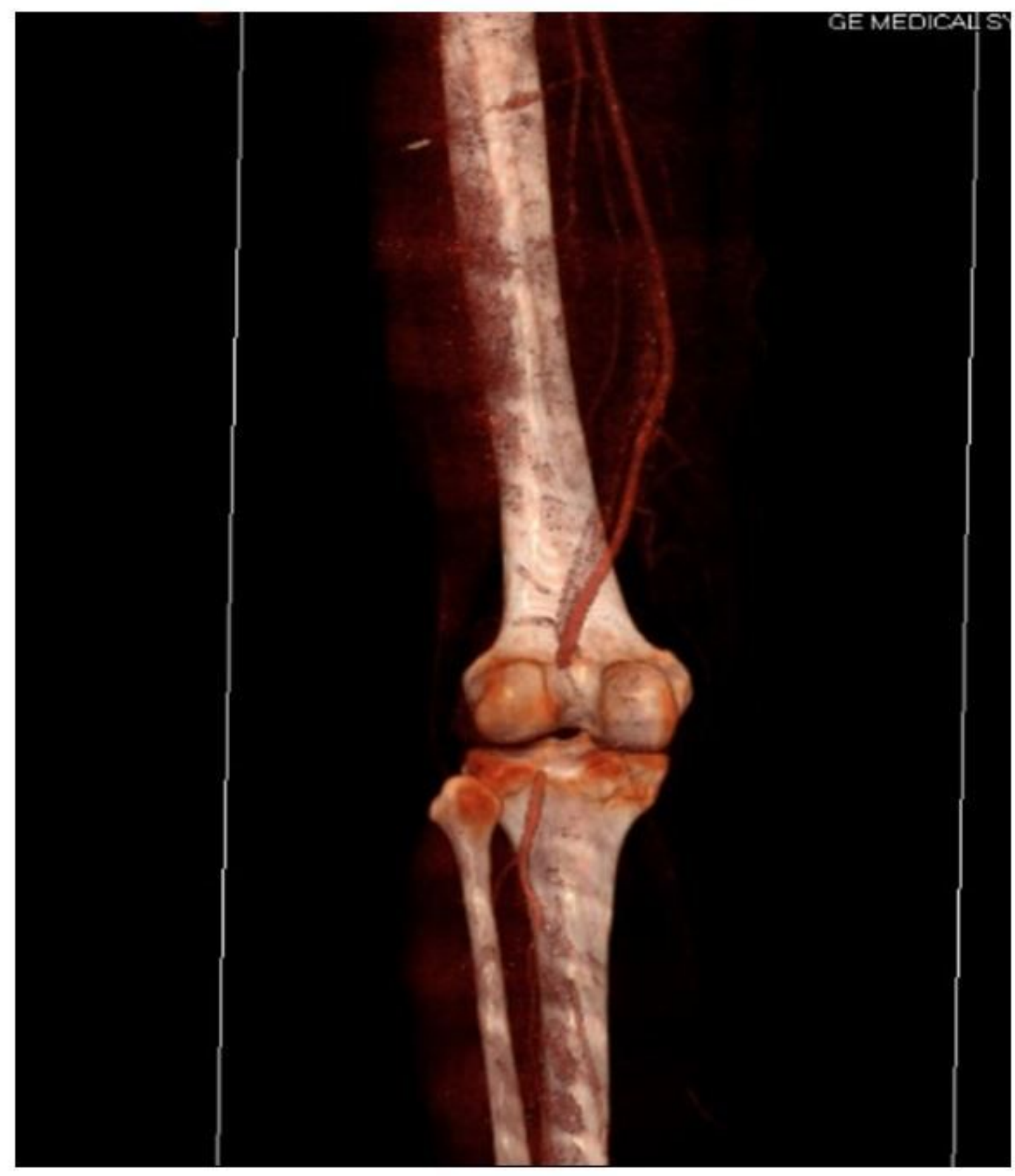

\section{Figure 2}

Pt $n^{\circ} 7$ CT scan of lower left limb: after reduction of dislocation, there is an interruption of the passage of the contrast medium in the retroarticular popliteal artery. 


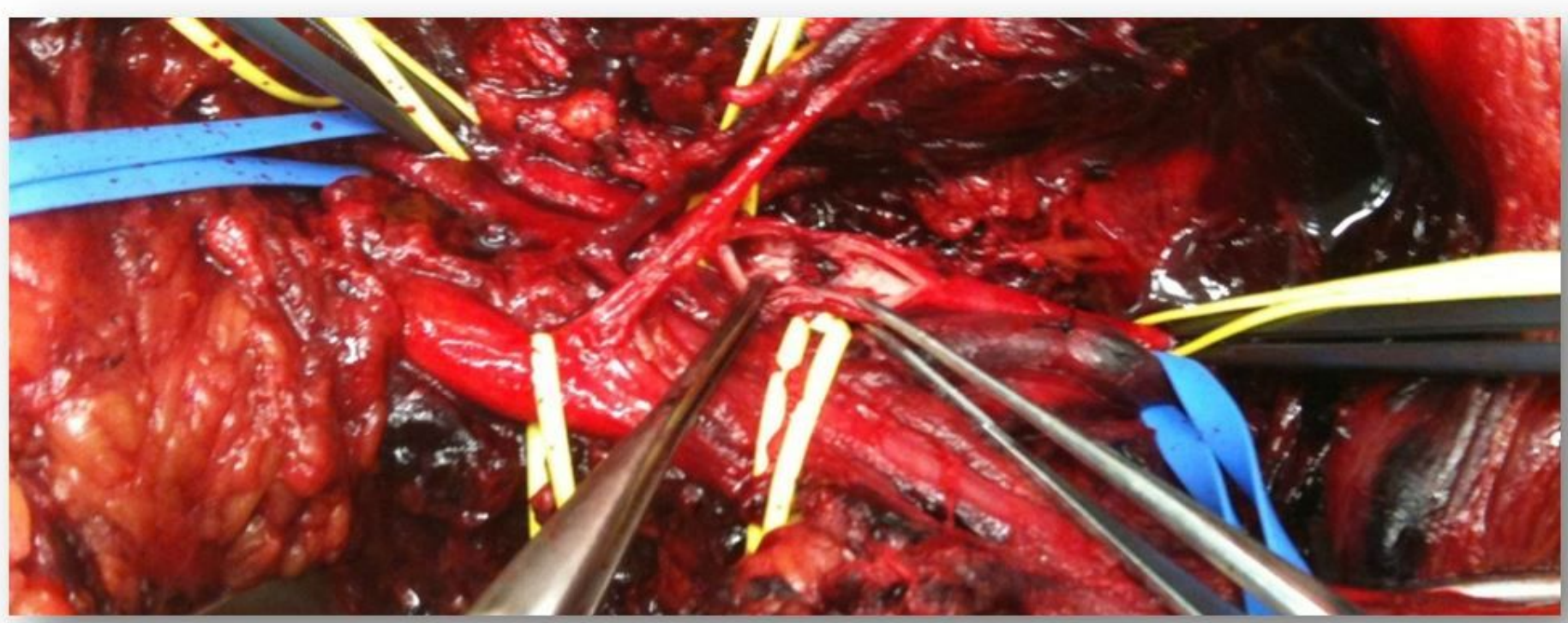

Figure 3

Pt $n^{\circ} 7$ Intraoperative image. Posterior popliteal surgical access. Popliteal artery clamping and longitudinal arteriotomy. After removal of the intraluminal clot note the interruption of the tunica intima, the seat of arterial trauma. 